\title{
IAMJ
}

INTERNATIONAL

AYURVEDIC

MEDICAL JOURNAL

\section{AYURVEDIC MANAGEMENT OF UPAVISHTAKA GARBHA DUE TO PIH AN INTEGRATED APPROACH - A SINGLE CASE STUDY}

\author{
Aswathi R S ${ }^{1}$, Sathish Jalihal ${ }^{2}$ \\ ${ }^{1}$ P G Scholar, Dept. of Prasuti Tantra and Streeroga, Alva's Ayurveda Medical College, Moodbidri, Karnataka, \\ India \\ ${ }^{2}$ Chief physician, MD (Ayu) in Prasuti Tantra and Streeroga, Dhatri Fertility Centre, Koppal, Karnataka, India
}

Corresponding Author: arspadikkal@gmail.com

\section{https://doi.org/10.46607/iamj4308092020}

(Published online: September 2020)

Open Access

(C) International Ayurvedic Medical Journal, India 2020

Article Received: 26/08/2020 - Peer Reviewed: 08/09/2020 - Accepted for Publication: 08/09/2020

\section{(A) Check for updates}

\section{ABSTRACT}

At present era it is observed that the incidence of normal pregnancy and delivery has been diminished. In childbirth weight is one of the most important factors affecting neonatal mortality and morbidity. Pregnancy induced hypertension is a global complication, approximately $10-17 \%$ of pregnancies are affected, and IUGR is one among the complications of PIH. In Ayurveda Samhithas, various Garbhavyapat are described and one among those are Upavishtaka Garbha. Acharya Charaka stated, as if bleeding per vagina or other types of discharges occur in pregnant woman, then the foetus will not grow properly in the uterus, and Acharyas mentioned many Chikitsas for the same. If IUGR is occurred due to PIH then most of the Chikitsas are to reduce PIH and to increase the weight of the baby. Hence can enlighten the treatment procedures in medical practice. Here is a single case study which reduces the PIH and promote the Foetal weight with Ksheerabasti with Gokshura and Yashtimadhu. Here both the drugs are having Vasodilatation property which reduces the hypertension in pregnant lady and increases the foetal blood flow. Ksheera is having Balya property which in turns the foetal growth, which gave significant action in the PIH and IUGR.

Keywords: Ayurveda Samhita, Garbha Vyapat, Upavishtaka Garbha, Gokshura Basti, Ksheera Basti 


\section{INTRODUCTION}

Being pregnant and ultimately being able to give birth to a life is a fulfilling experience for a woman. But complications associated with it may make it difficult experience for both mother and the child. PIH is one of such complication and they are responsible for $8-9 \%$ of maternal death in India. Overall, they complicate 5-10\% of pregnancies in India. In PIH, Oedema, Hypertension and Proteinuria are the cardinal symptoms whereas presence of headache, disturbed sleep, visual disturbances, Oliguria and Epigastric pain are considered as alarming features. IUGR is considered as one among the complications of PIH. On looking into the Ayurvedic classics we find clear description of symptoms related to severe PIH like pathological Oedema (Garbhini Shotha) ${ }^{1}$, convulsions (Akshepaka) ${ }^{2}$, Oliguria (Garbhini Mutragraha) ${ }^{3}$, IUGR (Garbha sosha $)^{4}$ etc. Acharyas had described these factors under the heading of Garbhopadrava. In classics, during pregnancy Masanumasika Garbhini Paricharya are described in detail which is very efficient in preventing the development of PIH.

\section{Materials and Methods}

Place of study: SJG Ayurvedic Medical College, Koppal

\section{Case Report:}

The present case study is successful Ayurvedic management of a case of Upavishtaka Garbha due to PIH. A 26 yrs old female patient came to the Ayurvedic hospital with chief complaint of;

1. Headache

2. Epigastric pain

3. Massive all over body Oedema

Associated symptoms: 1. Oliguria, 2. Decreased Fetal movements

Patient had above complaints for one week

History of present illness: 26 years old female patient with Primi Gravida of 27 weeks of gestation developed all over body Oedema gradually and her BP shows $180 / 120 \mathrm{~mm}$ of hg, and also her urine albumin was 4+. For this she consulted modern gynecologist. He convinced them to terminate the pregnancy and prophylactic Magnesium Sulphate was given ( $4 \mathrm{~g}$ IV and $10 \mathrm{~g} \mathrm{IM}$ ). But patient did not willing to terminate the pregnancy. So, she visited Ayurvedic hospital.

Past History: Nothing significant

Table 1: Personal History

\begin{tabular}{|l|l|l|}
\hline Name: XYZ & Habits: None & Prakruti: Pitta vata \\
\hline Age: 26 yrs & Bowel: Regular & BP: $180 / 120 \mathrm{~mm} \mathrm{hg}$ \\
\hline Sex: Female & Appetite: Reduced & Height: $160 \mathrm{~cm}$ \\
\hline Occupation: Housewife & Micturition: Reduced(once/day) & Weight: $50 \mathrm{~kg}$ \\
\hline Bala: Madhyama & Sleep: Disturbed & \\
\hline
\end{tabular}

Table 2: Ashtavidha Pareeksha

\begin{tabular}{|l|l|}
\hline Nadi :114bpm & Sabda: Clear \\
\hline Mutra: once a day & Sparsha: Normal \\
\hline Mala: Avibadha & Drik: Normal \\
\hline Jihwa: Lipta & Akruthi: Madhyama \\
\hline
\end{tabular}


Systemic Examination: CVS: S1 S2 heard, NAD, CNS: Conscious, well oriented, NAD, R.S:, NAD, GIT : NAD Table 3: Local examination:

\begin{tabular}{|l|l|l|}
\hline \multicolumn{1}{|c|}{$\mathbf{P} / \mathbf{A}$} & Palpation & Auscultation \\
\hline Inspection & $\begin{array}{l}\text { Fundal Height: 24-26 weeks (lesser } \\
\text { than the age of gestation) }\end{array}$ & FHR :136 beats/mint \\
\hline Linea Nigra: present & $\begin{array}{l}\text { Foetal parts are easily palpable due to } \\
\text { Oligohydramnios }\end{array}$ & \\
\hline $\begin{array}{l}\text { Striae Gravidarum: }++ \text { (due to disten- } \\
\text { tion of abdomen) }\end{array}$ & $\begin{array}{l}\text { Left longitudinal lie and Cephalic } \\
\text { presentation }\end{array}$ & \\
\hline $\begin{array}{l}\text { P/V } \\
\text { Inspection }\end{array}$ & & Bimanual Examination \\
\hline Vulval oedema: present: (++++) & Cervix: Healthy, posteriorly located, Oss closed \\
\hline Superficial Varicosities: Present & Discharge: Absent \\
\hline
\end{tabular}

\section{Investigations:}

1) USG: IUGR and EFW, FHR:133bpm, EFW:695g Doppler Study findings are: Cerebro placental ratioReduced
- $\quad \mathrm{B} / \mathrm{L}$ uterine artery showing increased resistance flow \& early diagnostic notch, there is the symptoms of severe uteroplacental \& placento foetal insufficiency

Table 4: Doppler findings before treatment

\begin{tabular}{|l|l|l|l|}
\hline & PI & RI & S/D Ratio \\
\hline MCA & 1.5 & 0.7 & 4.1 \\
\hline Umbilical artery & 2.1 & 1.0 & 0.0 \\
\hline Right Artery & 2.4 & 0.8 & 6.7 \\
\hline Left UTA & 1.2 & 0.6 & 2.7 \\
\hline
\end{tabular}

- SLIUP OF 28 weeks 4 days (calculated from LMP) showing a growth of 23 weeks 2 days $+/-2$ weeks size.

- Growth lag of $>5$ weeks with severe fetoplacental $\&$ uteroplacental insufficiency- early onset of IUGR (severe)

- Mild-moderate maternal ascites

2) Urine albumin: $4+$

3) $\mathrm{CBC}: \mathrm{Hb}: 13.10 \mathrm{~g} \%, \mathrm{Bl}$. urea: $20.80 \mathrm{mg} \%$, WBC:8,100cells/cumm

\section{Final diagnosis:}

Primi with severe pre-eclampsia with IUGR, As the pratyatma Lakshanas of Upavistaka Garbha like Vriddhim Aprapnuvan (Growth Retardation), Sasphura (Fetal Movements Appreciable) and Vardhate $\mathrm{Na}$ Udaram (Fundal Height Less than the period of Amenorrhoea) were present in this case, so Upavishtaka Chikitsa was followed.
Treatment Plan: Patient was treated in IPD basis Treatment

- Upavishtaka Garbha chikitsa

- Ksheerabasti with yashtimadhu-gokshura ksheerapaka $100 \mathrm{ml}$ daily for 8 days

Orally:

$\square$ Modern Gynecologist referred.

$\checkmark$ Tab. Labetelol $100 \mathrm{mg}$ 1TID

$\checkmark$ Tab. Nicardia $20 \mathrm{mg} 1 \mathrm{OD}$

$\checkmark$ Tab. Ecospirin $75 \mathrm{mg} 1 \mathrm{OD}$

$\checkmark$ Ayurvedic medications.

$\checkmark$ Tab. Limiron 1 TID

$\checkmark$ Yashtimadhu Gokshura Ksheerapaka $50 \mathrm{ml}$ BD $(\mathrm{B} / \mathrm{F})$

$\checkmark$ Cap. Sujat 1BD After Food X 10 Days

\section{Results}

- Vulval oedema completely resolved 
- Abdominal oedema relieved

- Pedal oedema reduced

- Urine albumin reduced to 3+

- Her BP reduced to $130 / 90 \mathrm{~mm}$ of $\mathrm{hg}$

- After 10 days USG repeated. Findings are; FHR:140bom, EFW:908g

\section{Doppler findings are.}

- Cerebroplacental ratio is reduced 0.66

- Uterine artery showing increased resistance flow

- Umbilical artery shows absent diastolic s/o moderate uteroplacental \& fetoplacental insufficiency

Table 5: Doppler finding after treatment

\begin{tabular}{|l|l|l|l|}
\hline & PI & RI & S/D Ratio \\
\hline MCA & 1.3 & 0.71 & 3.46 \\
\hline Umbilical Artery & 2.0 & 1.0 & 0.0 \\
\hline Right UTA & 2.0 & 0.79 & 4.86 \\
\hline Left UTA & 1.2 & 0.6 & 2.7 \\
\hline
\end{tabular}

- SLIUP of 29 weeks 5 days (calculated from LMP) showing a growth of 25 weeks 5 days $+/-2$ weeks size

- Growth lag of $>4$ weeks with moderate fetoplacental \&uteroplacental insufficiency-Early onset of IUGR

- Mild to moderate maternal ascitis.

\section{DISCUSSION}

Gokshura has Mutraghna, Balya, Sulaghna, Vatahara and Hridhya properties. Yashtimadhu is endowed with Raktashodhaka, Balya, Vata shamaka, and Kledahara properties. Emphasis of Ksheera in Garbhini is well known with properties such as Jeevaniya, Rasayana, Medhya, Balya, and Brahmana. All these two drugs along with Ksheera have good impact on growing fetus. Ksheera Basti with these drugs is found to increase fetal weight by Bruhmana, Balya, Pushtidayaka, Rasayana etc. properties by rejuvenating the Dhatus. Basti expels morbid wastes present in the intestines thereby it boosts the absorption of Ksheerabasti ingredients. It acting as Dhatuvardhaka increases Rasa Dhatu and increases the amniotic fluid. Gokshura will helps to increase the urine output which will reduces the oedema and it is lowering the hypertension. Yashtimadhu is act as Kledahara which will supply proper blood supply to the fetus which will manage the fetal growth and the Rasayana and Brahmana property of Ksheera will nourishes the fetus which inturn nourishes the foetus. Basti does the Vatanulomana and also normalizes the Vata, relieve pain abdomen also. And Gudha is considered as the Siramarma, if the medicine is reaches there it will supply to all over body and whole body will get the nourishment.

\section{CONCLUSION}

Gokshura Yashtimadhu Ksheerapaka drugs act as $\mathrm{Mu}$ trala, Kledahara, Rasayana and Dhatuvardhaka by constructive metabolism and thus have definite action on fetal growth-related disorders. It also improves the amniotic fluid, fetal growth, maternal wellbeing and relieves oliguria, odema, bodyache etc. Therefore, the present case series focusing to use of Gokshura Yashtimadhu Ksheerabasti, these drugs will be more effective in counteracting IUGR with its anabolic properties without any side effect. This study also throws light on the future scope of management of IUGR in Prasuti Tantra practice. Because every time, termination of pregnancy is not an option. We can use alternative ways to save the child. Being a mother will be a wonderful feeling and being a mother of a healthiest baby will be a bliss.

\section{REFERENCES}

1. P. Haridas Tripathi, Harivyakhya, Haritha Samhitha, Choukamba Krishnadas Academy, Varanasi,2015, $3^{\text {rd }}$ chapter 51 st sloka

2. Pandit Hemarajasharma Srisatyapala Baishajyacharya, Kashyapa Samhita, Choukamba Samlshepa Samsthana, Varanasi, 2008.Ka. Khi10/111-113 
3. Pandit Hemarajasharma Srisatyapala Baishajyacharya, Kashyapa Samhita, Choukamba Samlshepa Samsthana, Varanasi, 2008. Ka.Khi10/144-145,p.no 293

4. Pt K N Shasthry \& G N Chadurvedi, Vidyotini vyakhya, Charaka Samhitha Choukamba Bharati Academy Part I 2005, Cha.Sam 2/15 p.no 841

\section{Source of Support: Nil \\ Conflict of Interest: None Declared}

How to cite this URL: Aswathi R S \& Sathish Jalihal: Ayurvedic Management Of Upavishtaka Garbha Due To Pih An Integrated Approach - A Single Case Study. International Ayurvedic Medical Journal \{online\} 2020 \{cited September, 2020\} Available from: http://www.iamj.in/posts/images/upload/4560_4564.pdf 